\title{
Influence of Fluorine on Clinker burnability and mechanical properties of CPA Moroccan cement
}

\author{
A. Bouregba* ${ }^{1}$, A. Diouri ${ }^{1}$, B. Elghattas ${ }^{2}$, A. Boukhari ${ }^{1}$ and T. Guedira ${ }^{2}$ \\ ${ }^{1}$ Mohammed V University, Faculty of science, Rabat, Morocco \\ ${ }^{2}$ Ibn Tofail University, Faculty of science, Kenitra, Morocco
}

\begin{abstract}
It has been found that the addition of certain components, despite their low concentration in raw mix, may accelerate and enhance the reactivity of the cement raw mix. The utilization of mineralizers to facilitate and quicken the process of clinkerization backpedals numerous years, the concept of using such mineralizers to burn normal raw mixes at a much lower temperature with the end goal of decreasing the fuel necessities of the furnace and to enhance the cement proprieties has become to be seriously considered over the most recent couple of years.

The subject of this paper is to investigate the impact of calcium fluoride as mineralizer on addition during the clinkerization process of industrial raw mixtures and its effect on chemical, mineralogical, and mechanical properties of CPA Moroccan cement. Five different raw meals were utilized and were burned with $2 \%$ of calcium fluoride. The resulting clinker was analyzed by X-ray diffraction (XRD) and fluorescence spectroscopy to determine the chemical phases of the obtained clinker, and the mechanical properties of resulting CPA cement were determined. The results show that the addition of $2 \%$ of $\mathrm{CaF}_{2}$ to the clinker raw meal induced a decrease in the burning temperature and free lime, while improving the clinker phase formation and the mechanical properties of obtained cement.
\end{abstract}

\section{Introduction}

In the recent years many studies have concentrated on the investigation of processing production of clinkers at the lowest temperature than those regularly experienced, while in the meantime producing a better quality product that fulfills Requirements of various standards. The utilization of mineralizers to facilitate the process of clinkerization goes back many years, in the aim of reducing the fuel requirements of the kiln and to improve the cement proprieties [1-5].

Mineralizers are inorganic substances which quicken the reaction process in the solid-liquid interface, liquid phase and in the solid phase [1]. Several works, carried out in different laboratories demonstrate that the addition of a small quantities of these mineralizers have a major impact on the determination of the burning zone clinkerization and the percentage of clinker compound formation. They majorly affect the determination of the burning zone and the clinker compound formation, they can also facilitate and quick the clinkerization process, by decreasing the liquid phase temperature and mineral fusible eutectic in the aim of saving the clinker production energy and improving the cement compound reactivity $[2,3]$. They can also improve the hydraulic properties of clinker [3, 6-13]

The aim of this work was to examine the impact of calcium fluoride mineralizer $\left(\mathrm{CaF}_{2}\right)$ on the decreasing temperature of burning of Moroccan industrial raw mixtures, and to study it effect on chemical, mineralogical, and mechanical properties of the clinker cement. This mineralizer is added separately to five categories of industrial raw mixtures of Moroccan cement factory.

\section{Materials and method}

The raw material used in this study is of the industrial type; it comes from deposits operated by the Moroccan cement company. The wines were prepared and characterized. The chemical analysis of five samples (M01-M05) was determined by X-ray fluorescence, their chemical analyses are shown in Table 1.

The mixtures were burned at different temperatures: $1300,1350,1400$ and $1450{ }^{\circ} \mathrm{C}$. Crystallized phases in the clinker minerals were identified by X-ray diffraction with a Siemens D5000 diffractometer operating with 40kV and $20 \mathrm{~mA}$, equipped with a copper anticathode and a 
secondary monochromator $(\lambda=1.5406 \AA)$. The acquisition interval in angle $2 \theta$ is between 10 and $60^{\circ}$ in steps of $0.04^{\circ}$ with an accumulation of a second per step. The cements is obtained by by adding $3 \%$ gypsum to the elaborate cements. Mechanical and physical tests on the cements were carried out. The addition effects on the mechanical resistance of these products were determined. The mineralizer effectiveness was compared to the ordinary clinker produced by the Moroccan cement factory

Table 1. Chemical analyse of the raw mixture (wt.\%)

\begin{tabular}{|c|c|c|c|c|c|}
\hline & $\mathbf{M 0 1}$ & $\mathbf{M 0 2}$ & $\mathbf{M 0 3}$ & $\mathbf{M 0 4}$ & $\mathbf{M 0 5}$ \\
\hline $\mathrm{SiO}_{2}$ & 13,49 & 13,68 & 13,88 & 14,47 & $\begin{array}{c}13,0 \\
5\end{array}$ \\
\hline $\mathrm{Al}_{2} \mathrm{O}_{3}$ & 3,25 & 3,55 & 3,25 & 3,74 & 3,53 \\
\hline $\mathrm{Fe}_{2} \mathrm{O}_{3}$ & 2,33 & 2,27 & 2,24 & 2,17 & 2,14 \\
\hline $\mathrm{CaO}$ & 42,45 & 43,49 & 44,11 & 46,28 & $\begin{array}{c}46,7 \\
4\end{array}$ \\
\hline $\mathrm{MgO}$ & 1,34 & 1,26 & 1,42 & 1,28 & 1,24 \\
\hline $\mathrm{SO}$ & 0,27 & 0,38 & 0,49 & 0,42 & 0,33 \\
\hline $\mathrm{K}_{2} \mathrm{O}$ & 0,57 & 0,67 & 0,58 & 0,68 & 0,67 \\
\hline $\mathrm{TiO}$ & 0,2 & 0,2 & 0,22 & 0,11 & 0,09 \\
\hline $\mathrm{MnO}$ & 0,06 & 0,05 & 0,06 & 0,05 & 0,05 \\
\hline $\mathrm{P}_{2} \mathrm{O}_{5}$ & 0,12 & 0,1 & 0,12 & 0,11 & 0,09 \\
\hline $\mathrm{LSF}$ & 96 & 98 & 100,57 & 101,9 & 104 \\
\hline $\mathrm{MS}$ & 2,51 & 2,36 & 2,51 & 2,39 & 2,3 \\
\hline $\mathrm{A} / \mathrm{F}$ & 1,53 & 1,58 & 1,43 & 1,61 & 1,65 \\
\hline
\end{tabular}

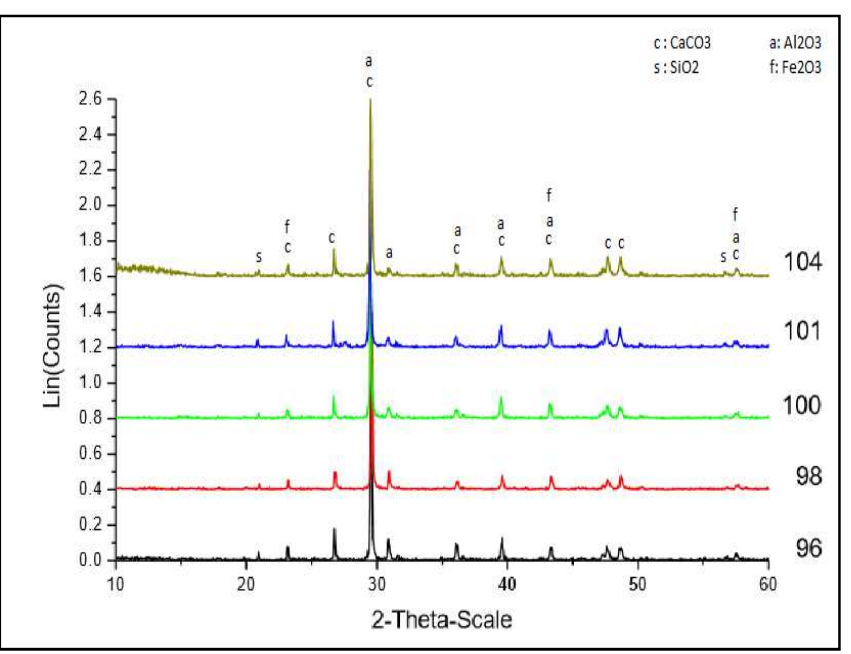

Fig. 1. XRD pattern of five raw mix materials

This investigation studies consists to add $2 \%$ of $\mathrm{CaF}_{2}$ to raw mix and study its impact on the temperature of burning, on the free lime, on the clinker mineral phases formation and on the mechanical strengths

\section{RESULTS AND DISCUSSION}

\subsection{Effect of Calcium fluoride on the free lime}

The results of the table 2 shows the evolution of the free lime $\left(\mathrm{CaO}_{\mathrm{f}}\right)$ content in both case with LSF equal to 98 and 100.57 in addition of $\mathrm{CaF}_{2}(0$ and 2\%) mineralizer at different temperatures from $1300{ }^{\circ} \mathrm{C}$ to $1450{ }^{\circ} \mathrm{C}$. The favorable effect of these substances on the clinkerization process for the two crus studied is clearly compared to the case without mineralization. However, the beneficial effect of adding $\mathrm{CaF}_{2}$ mineralizers is significativelly remarkable at low temperatures (1300 and $1350{ }^{\circ} \mathrm{C}$ ) for the both factor lime saturation (LSF). From the table above we observed a decrease of free lime rate when $\mathrm{CaF}_{2}$ content is increase. this reduction of $\mathrm{CaO}_{\mathrm{f}}$ is due to increase in the speed of the solid-state reaction resulting to the easy diffusion effect of fluorine and the acceleration of the necessary reactions for clinker phase formation due to the low-viscosity fluorine melts [6-7].

Table 2. wt. $\% \mathrm{CaO}_{\mathrm{f}}$ according to the burning temperature, $\%$ of mineralizer and LSF

\begin{tabular}{|c|c|l|l|l|}
\hline $\mathbf{L S F}$ & \multicolumn{2}{|c|}{$\mathbf{1 0 0 . 5 7}$} & \multicolumn{2}{c|}{$\mathbf{9 8}$} \\
\hline \% of $\mathbf{C a F}_{\mathbf{2}}$ & $\mathbf{0}$ & $\mathbf{2}$ & \multicolumn{1}{|c|}{$\mathbf{0}$} & $\mathbf{2}$ \\
\hline $\mathrm{CaO}_{\mathrm{f}}\left(1300^{\circ} \mathrm{C}\right)$ & 5,84 & 3,64 & 5,432 & 2,912 \\
\hline $\mathrm{CaO}_{\mathrm{f}}\left(1350^{\circ} \mathrm{C}\right)$ & 3,92 & 2,52 & 3,864 & 2,35 \\
\hline $\mathrm{CaO}_{\mathrm{f}}\left(1400^{\circ} \mathrm{C}\right)$ & 3,52 & 1,792 & 2,52 & 1,56 \\
\hline $\mathrm{CaO}_{\mathrm{f}}\left(1450^{\circ} \mathrm{C}\right)$ & 0,95 & 0,53 & 0,84 & 0,46 \\
\hline
\end{tabular}

\subsection{Action of $\mathrm{CaF}_{2}$ on clinker mineral phase's formation}

The development of clinker formation was followed mostly on the basis of the free lime $(\mathrm{CaOf})$ contained in the burned samples. It is the most utilized procedure so far because calcium oxide, which formed by dissociation of $\mathrm{CaCO}_{3}$, is gradually consumed by giving clinker phases. The formation of these phases will be reached when the free lime content is much lower, in same case tend to 0 [3].

The clinkers obtained by burning the raw mixtures at $1400{ }^{\circ} \mathrm{C}$ without and with $2 \% \mathrm{CaF}_{2}$ and at $1450{ }^{\circ} \mathrm{C}$ without mineralizer are investigated. The ordinary clinker burned at $1450{ }^{\circ} \mathrm{C}$, has been taken for comparison. The weight percentages of clinker minerals [alite $\left(\mathrm{C}_{3} \mathrm{~S}\right)$, belite $\left(\mathrm{C}_{2} \mathrm{~S}\right), \quad 3 \mathrm{CaO} \cdot \mathrm{Al}_{2} \mathrm{O}_{3}\left(\mathrm{C}_{3} \mathrm{~A}\right)$ and $4 \mathrm{CaO} \cdot \mathrm{Al}_{2} \mathrm{O}_{3} \cdot \mathrm{Fe}_{2} \mathrm{O}_{3}$ $\left(\mathrm{C}_{4} \mathrm{AF}\right)$ ] were calculated compared to the crystallized mass, by using the following Bogue method:

$$
\begin{aligned}
& \mathrm{C}_{3} \mathrm{~S}=4.07 \mathrm{CaO}-7.602 \mathrm{SiO}_{2}-6.72 \mathrm{Al}_{2} \mathrm{O}_{3}-1.43 \mathrm{Fe}_{2} \mathrm{O}_{3} \\
& \mathrm{C} 2 \mathrm{~S}=2.87 \mathrm{SiO}_{2}-0.754 \mathrm{C}_{3} \mathrm{~S} \\
& \mathrm{C}_{3} \mathrm{~A}=2.65 \mathrm{Al}_{2} \mathrm{O}_{3}-1.69 \mathrm{Fe}_{2} \mathrm{O}_{3} \\
& \mathrm{C}_{4} \mathrm{AF}=3.04 \mathrm{Fe}_{2} \mathrm{O}_{3}
\end{aligned}
$$


Table 3, figures 2-4 summarized the mineral composition of the elaborated clinkers phases after burning in different temperatures. The weight rate of each phase in the studied clinkers is impacted by the temperature of burning and by the presence of Calcium fluoride mineralizer $\mathrm{CaF}_{2}$. The presence of the latter increases the weight rate of Alite $\left(\mathrm{C}_{3} \mathrm{~S}\right)$, besides it decreases the weight of free lime $\left(\mathrm{CaO}_{\mathrm{f}}\right)$ and the one of bélite $\left(\mathrm{C}_{2} \mathrm{~S}\right)$, The weight rate of others phases is very close.

The presence of the mineralizer quickens the clinker minerals development. This impact is caused principally by the presence of fluoride anions, characterized by high electronegativity; this latter reacted with the ions $\left(\mathrm{Ca}^{2+}\right.$, $\mathrm{Si}^{4+}$ ) on the solid surface. This latter is kept up in a highenergy state, entraining to polarization and rearrangement of atoms, which expand the solid activity either to form new phases, or to melt. However the presences of $\mathrm{F}^{-}$in the mixture quicken the lime combination by forming the belite phase $\left(\mathrm{C}_{2} \mathrm{~S}\right)$ with the appearance of the amorphous phase, which improves the alite $\left(\mathrm{C}_{3} \mathrm{~S}\right)$ formation [3].

Table 3: Mineralogy of clinkers

\begin{tabular}{|c|c|c|c|c|c|}
\hline Samples & $\mathbf{C a O}$ & $\begin{array}{c}\mathrm{Ca}_{3} \mathrm{SiO}_{5} \\
\left(\mathbf{C}_{3} \mathbf{S}\right)\end{array}$ & $\begin{array}{c}\boldsymbol{\beta}- \\
\mathbf{C a}_{2} \mathbf{S i O}_{4} \\
\left(\mathbf{C}_{2} \mathbf{S}\right)\end{array}$ & $\begin{array}{c}\mathbf{C a}_{4} \mathbf{A l}_{2} \mathbf{F e}_{2} \mathbf{O}_{\mathbf{1 0}} \\
\left(\mathbf{C}_{\mathbf{4}} \mathbf{A F}\right)\end{array}$ & $\begin{array}{c}\mathbf{C a}_{3} \mathbf{A l}_{2} \mathbf{O}_{\mathbf{6}} \\
\left(\mathbf{C}_{3} \mathbf{A}\right)- \\
\text { cubique }\end{array}$ \\
\hline $\mathrm{CP} 1$ & 1,96 & 59,60 & 16,51 & 9,64 & 6,97 \\
\hline $\mathrm{K} 1$ & 3,52 & 58,10 & 15,23 & 10,15 & 7,37 \\
\hline $\mathrm{K} 3$ & 1,792 & 78,47 & 2,21 & 9,03 & 7,33 \\
\hline
\end{tabular}

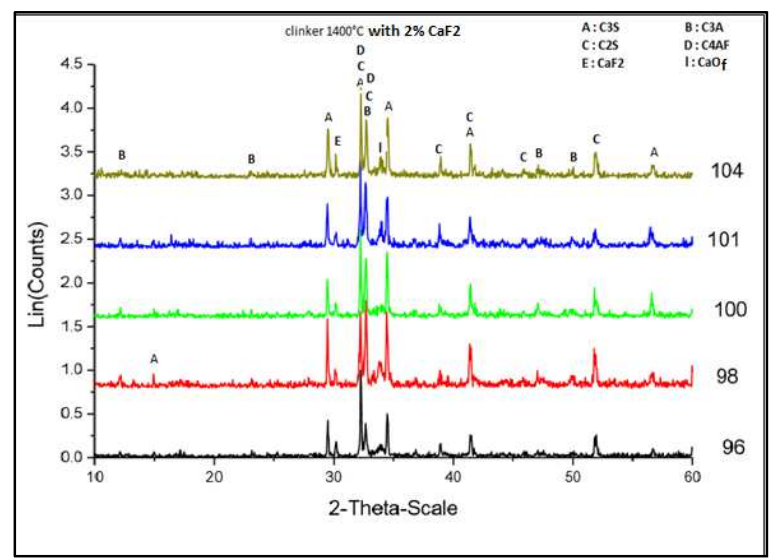

Fig. 2. XRD pattern of Clinker burned at $1400^{\circ} \mathrm{C}$ with $2 \%$ of $\mathrm{CaF}_{2}$ With different LSF

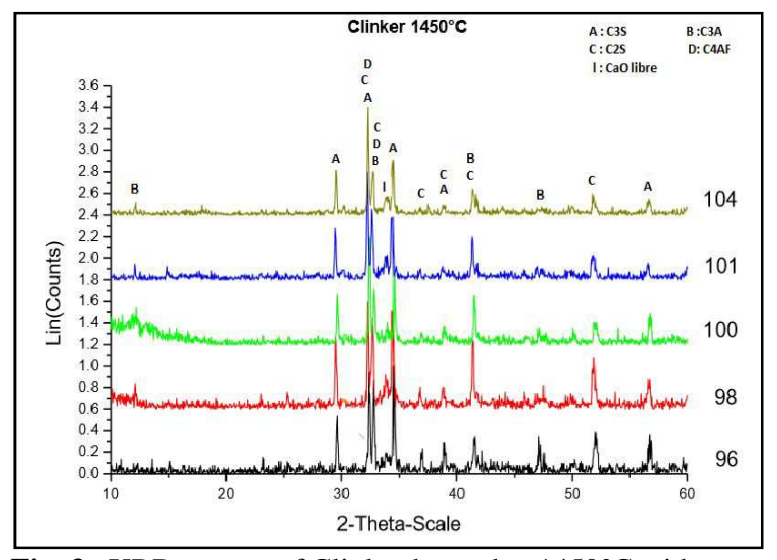

Fig. 3. XRD pattern of Clinker burned at $1450^{\circ} \mathrm{C}$ without $\mathrm{CaF}_{2}$ With different LSF

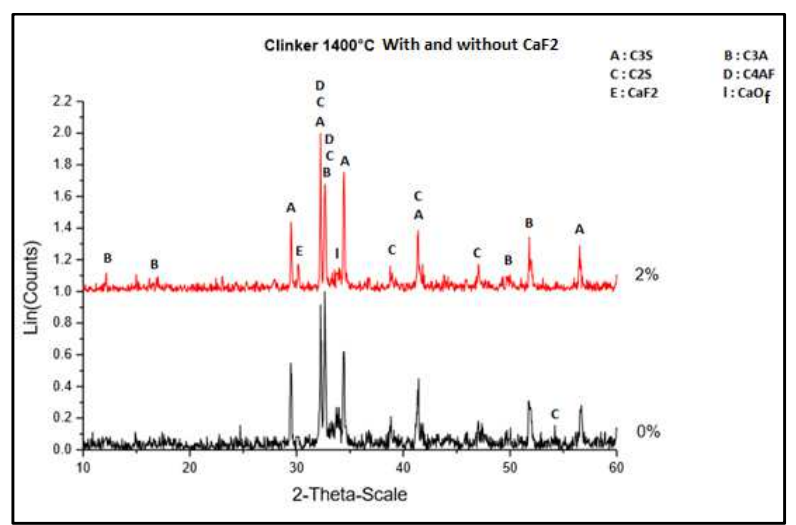

Fig. 4. XRD pattern of Clinker burned at $1400^{\circ} \mathrm{C}$ with and without $\mathrm{CaF}_{2}(\mathrm{LSF}=100.57)$

\subsection{Mechanical strength}

The results of compressive and bending strengths of prepared cements, determined by mechanical tests are given in Fig 5 and 6.

The compressive and bending strengths of clinker cement are affected by $\mathrm{CaF}_{2}$ addition at short and long times. The mechanical strength values of clinker containing $2 \%$ of $\mathrm{CaF}_{2}$ burning at $1400^{\circ} \mathrm{C}$ is higher than those developed by the industrial cement, clinker burning at $1450{ }^{\circ} \mathrm{C}$ and $1400^{\circ} \mathrm{C}$ without $\mathrm{CaF} 2$. On one hand this is due to fast formation of alite and belite in this clinker and on other hand it is due to percentage weight of alite higher affected by the presence of mineralizer [3].

The presence of $\mathrm{CaF}_{2}$ in the processes of clinkerization influence the parameter process like temperature of burning, percentage of free lime, clinker phases and also the mechanical strength. L. Kacimi et al., Demonstrated that the presence of alkalines fluorides can affect physical, structural and morphological proprieties. Of a clinker reached at $1300{ }^{\circ} \mathrm{C}$ with $1 \% \mathrm{CaF}_{2}$. This latter improve the structural properties of clinker minerals, which prompt to the improvement of the cement hydraulic properties, which increase the $\mathrm{C} 3 \mathrm{~S}$ rate in the obtained clinker phases wich impact the mechanical strength [3]. 


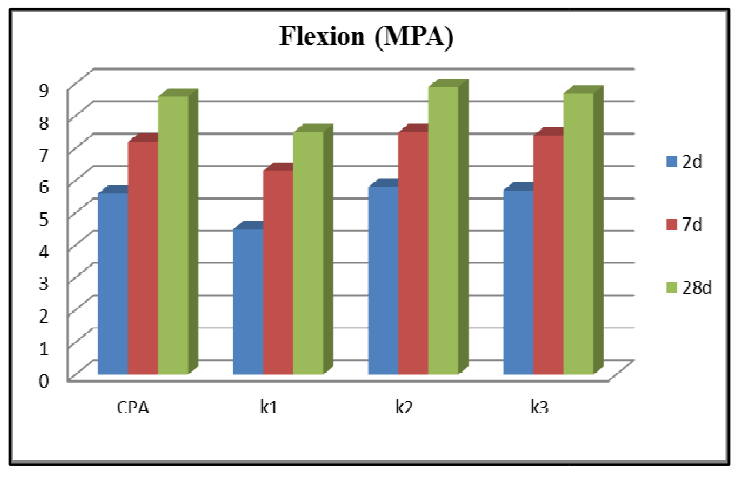

Fig. 5. Flexion strengths of prepared cements

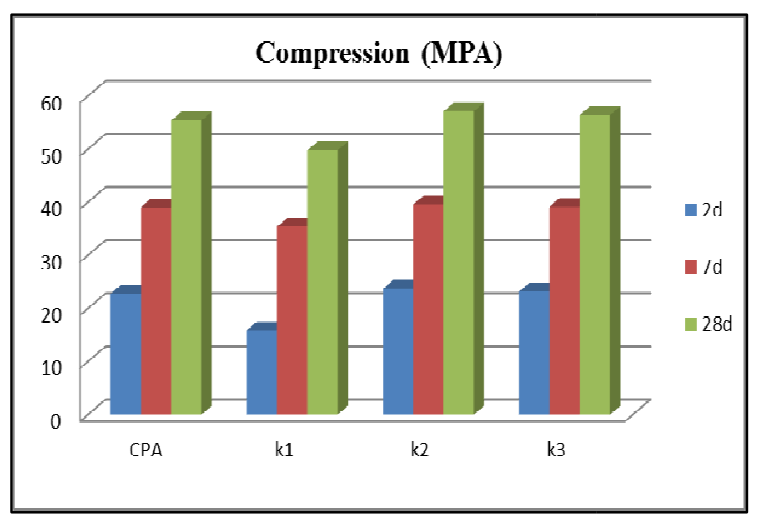

Fig. 6. Compression strengths of prepared cements

\section{Conclusion}

In this paper, the chemical and mineralogical analyses are carried out on clinkers from Moroccan cement factory. The investigation of addition a small amount of $\mathrm{CaF}_{2}(2 \%)$ during the clinkerization process, demonstrated a satisfactory results without impacting the product quality.

The presence of $\mathrm{CaF}_{2}$ can decrease the temperature of burning and the percentage of free lime. A clinker obtained at $1400{ }^{\circ} \mathrm{C}$ with the addition of $2 \%$ of $\mathrm{CaF}_{2}$ have a high rate of alite which improve the mechanical strength at short and long time in comparison of other clinkers.

\section{References}

1. M. Benchanaa, A. Kamali, Ann. Chim. Sci. Mat, 25 (2000)

2. M.T. Blanco-Varela, A. Palomo and T. Vázquez, Cement and Concrete Research, 14 (1984)

3. L. Kacimi A.S. Masseron, A. Ghomari, Z. Derriche, C. R. Chimie, 9 (2006)

4. W.A. Klenm, I. Jawed, and K.J. Holub, Cement and Concrete Research, 9 (1979)

5. I. García-Díaz, J.G. Palomo, F. Puertas, Cement \& Concrete Composites 33 (2011)
6. F. Puertas, M.T. Blanco-Varela, T. VBzquez and A. Palomo, Cement and Concrete Research, 269 (1996)

7. I.Akin Altun, Cement and Concrete Research, 29 (1999)

8. C. Gilioli, F. Massazza and M. Pezzuoli, Cement and Concrete Research, 9 (1979)

9. K. Raina and L.K. Janakiraman, Cement and Concrete Research, 288 (1998)

10. G. Kakali, S. Tsivilis, K. Kolovos, K. Choupa, T. Perraki, M. Perraki M. Stamatakis, Ch. Vasilatos, Materials Letters 57 (2003)

11. K.G. Kolovos, Cement \& Concrete Composites 28 (2006)

12. I. Jawed and J. Skalny, Cement and Concrete Research, 7 (1977)

13. Salim A. Alimmaryi and Ferenc D. Tamás, Cement and Concrete Research, 10 (1980) 